\title{
Perbandingan Warna Tepung Suweg Fase Dorman dan Vegetatif Secara Instrumental dan Sensoris
}

\author{
Umar Hafidz Asy'ari Hasbullah dan Rini Umiyati \\ Program Studi Teknologi Pangan Universitas PGRI Semarang \\ Email : umarhafidzah@upgris.ac.id; umarhafidzah@gmail.com
}

\begin{abstract}
Abstrak
Warna tepung mempunyai peranan penting karena akan berpengaruh terhadap warna produk turunan yang dihasilkan. Penelitian ini bertujuan untuk membandingkan warna tepung suweg yang dihasilkan dari fase dorman dan vegetatif secara instrumental dan sensoris. Instrument menggunakan Chromameter. Parameter yang diamati nilai $L^{*}, a^{*}, b^{*}$, chroma, dan derajat hue. Pengujian sensoris menggunakan uji rangking terhadap kesukaan warna, warna coklat dan kecerahan warna. Hasil penelitian menunjukkan bahwa terdapat perbedaan nyata pada nilai $L^{*}, a^{*}, b^{*}$, dan chroma antara tepung fase dorman dan vegetatif. Nilai derajat hue tidak berbeda nyata antar kedua perlakuan. Panelis menyatakan $100 \%$ menyukai warna tepung fase dorman dibandingkan vegetatif. Selain itu warna tepung fase vegetatif dinilai lebih dari $80 \%$ panelis menyatakan lebih coklat dan lebih dari $90 \%$ panelis menyatakan lebih gelap dibandingkan dorman. Hasil uji korelasi pearson menunjukkan terdapat beberapa yang berkorelasi antara parameter instrument dan sensoris.
\end{abstract}

Kata Kunci: tepung suweg, warna, dorman, vegetatif, chroma, hue

\begin{abstract}
The color of the flour has an important role because it will happen to the resulting derived product. This study was to compare the color of suweg flour produced from the dormant and vegetative phases in instrumental and sensory. Instruments using Chromameter. Parameters observed from $L^{*}, a^{*}, b^{*}$, chroma, and hue degrees. Sensory testing uses a rank test of color preferences, brown color and color brightness. The results showed significant differences in $L^{*}, a^{*}, b^{*}$, and chroma values between dormant and vegetative phase flours. The degree value of hue was not significantly different between the two treatments. Panellists stated $100 \%$ liked the color of the dormant flour stage than vegetative.Additionally, the color of the vegetative phase flour was assessed by more than $80 \%$ of the panelists claiming to be more brown and more than $90 \%$ of the panelists stated darker than dormant. Pearson correlation test results show that there are correlation in some parameter of instrument and sensory.
\end{abstract}

Keywords: suweg flour, color, dormant, vegetative, chroma, hue

\section{PENDAHULUAN}

Warna memegang peranan penting terhadap karakteristik bahan maupun produk pangan. Warna menjadi salah satu perameter mutu suatu produk pangan dan juga bahan bakunya. Warna dapat ditentukan dengan instrument maupun uji sensoris. Instrumen yang umumnya digunakan ialah chromameter. Parameter yang dapat diamati diantaranya nilai chroma, derajat hue, nilai $a^{*}, b^{*}$ dan kecerahan (McGuire, 1992). Uji sensoris dapat dilakukan dengan menggunakan panelis untuk mendapatkan data objektif kesukaan terhadap warna dan deskripsi warna menurut pengamatan panelis.

Beberapa peneliti sebelumnya menyatakan bahwa perbedaan fase dorman dan vegetatif menyebabkan perbedaan kandungan kimia termasuk gula reduksi dan protein (Hasbullah dan Umiyati, 2016). Dua komponen tersebut berperan dalam reaksi pencoklatan non enzimatis melalui reaksi Maillard. Hal tersebut akan berkontribusi terhadap warna tepung yang dihasilkan dari fase dorman maupun vegetatif. 
Agrisaintifika

Jurnal Ilmu-Ilmu Pertanian

Vol. 1, No. 1, 2017

Hasbullah \& Umiyati, 2017

Penelitian ini bertujuan untuk membandingkan warna tepung suweg dari fase dorman dan vegetatif secara instrumental dan sensoris.

\section{METODE}

Bahan yang digunakan yaitu umbi suweg yang diambil ketika fase dormansi dan fase vegetatif yang diperoleh di Kecamatan Banjarmangu, Kabupaten Banjarnegara, Jawa Tengah.

Tepung umbi suweg diperoleh berdasarkan prosedur yang mengacu pada Septiani, dkk. (2015) dengan modifikasi tanpa perendaman $\mathrm{HCl}$ dan $\mathrm{CaCO}_{3}$. Umbi suweg dikupas kemudian dicuci. Selanjutnya diiris dengan ketebalan 1-2 mm, dilanjutkan pengeringan pada suhu $60{ }^{\circ} \mathrm{C}$ selama 24 jam. Tahap berikutnya ditepungkan dan diayak 60 mesh. Tepung suweg disimpan dalam plastik HDPE sampai dianalisis.

Warna tepung dianalisis nilai chroma $(C)$, hue (oh), $a^{*}, b^{*}$ dan kecerahan $\left(L^{*}\right)$ dengan menggunakan chromameter (Faridah, 2005). Nilai $a^{*}$ positif menunjukkan hue merah-ungu; $a^{*}$ negatif menunjukkan biru-hijau; nilai $b^{*}$ positif menunjukkan kuning; $b^{*}$ negatif menunjukkan biru; nilai $L^{*}$ berkisar dari 0 (hitam) sampai 100 (putih); nilai C menunjukkan intensitas warna dari rendah (pudar) sampai tinggi (pekat), chroma diperoleh dari rumus $\left[\left(a^{* 2}+b^{* 2}\right)^{1 / 2}\right]$; nilai oh diperoleh dari rumus arctangent $b^{*} / a^{*}$ dan menunjukkan $0^{\circ}$ (merah-ungu), 90 (kuning), 180 (kebiruan-hijau) dan 270。 (biru) (McGuire, 1992). Uji sensoris dilakukan dengan uji rangking terhadap kesukaan, warna coklat dan kecerahan.

Data hasil pengujian dianalisis dengan uji t dan korelasi. Apabila hasil analisis tersebut menunjukkan berbeda nyata antara perlakuan, maka dilanjutkan dengan uji Duncan multiple range test (DMRT) pada taraf $5 \%$.

\section{HASIL DAN PEMBAHASAN}

Nilai parameter warna secara instrumental dengan menggunakan chromameter ditunjukkan pada Tabel 1. Intensitas kecerahan warna $\left(L^{*}\right)$ tepung suweg fase dorman berbeda nyata dengan vegetatif. Warna tepung dari fase dorman lebih cerah dibandingkan vegetatif. Hal ini dimungkinkan terjadi karena pencoklatan yang terjadi pada tepung fase vegetatif lebih banyak dibanding dorman. Kandungan gula reduksi dan protein pada fase dorman lebih banyak dari fase vegetatif. Selain itu kandungan pati pada fase dorman lebih tinggi dibanding vegetatif (data tidak ditampilkan).

Nilai $L^{*}$ hasil penelitian ini berbeda dengan Faridah (2005) yang menyatakan nilai $L^{*}$ tepung suweg 60. Sedangkan Hasbullah dkk. (2017) menyatakan bahwa nilai $L^{*}$ tepung suweg dari beberapa kabupaten di Jawa Tengah berada pada range 59-69. Paramita dkk. (2017) menyatakan bahwa tepung suweg dari Gunungpati Semarang memiliki nilai $L^{*}$ 62,49 . Beberapa peneliti lainnya menyatakan kecerahan tepung suweg dengan color reader memiliki nilai 57,7\% (Septiani dkk., 2015) dan $39 \%$ (Richana dan Sunarti, 2004). Nilai L* tepung suweg hasil penelitian ini jauh lebih rendah dibandingkan dengan tepung cassava $(90,21)$ (Uchechukwu-Agua dkk., 2015); (9395) (Oduro-Yeboah dkk., 2010), tepung talas (87-92) (Apriani dkk., 2011); (91,4) (Baidoo dkk., 2014), tepung ubi jalar (79-101) (Olatunde dkk., 2016); (86) (Sanoussi dkk., 2013).

Tabel 1. Warna Tepung suweg fase dorman dan vegetatif secara instrumental

\begin{tabular}{ccc}
\hline Parameter & Fase Dorman & $\begin{array}{c}\text { Fase } \\
\text { Vegetatif }\end{array}$ \\
\hline $\mathrm{L}^{*}$ & $58,84 \pm 2,1 \mathrm{a}$ & $53,92 \pm 1,8 \mathrm{~b}$ \\
$\mathrm{a}^{*}$ & $-14,88 \pm 1,1 \mathrm{a}$ & $-17,36 \pm 1,4 \mathrm{~b}$ \\
$\mathrm{~b}^{*}$ & $24,43 \pm 0,9 \mathrm{a}$ & $29,04 \pm 1,1 \mathrm{~b}$ \\
$\mathrm{C}$ & $28,62 \pm 1,0 \mathrm{a}$ & $33,85 \pm 1,5 \mathrm{~b}$ \\
oh & $121,33 \pm 1,9 \mathrm{a}$ & $120,84 \pm 1,6 \mathrm{a}$ \\
\hline
\end{tabular}

Notasi huruf yang sama menunjukkan tidak beda nyata pada $\alpha=0.05$. Data disajikan \pm standard deviasi.

Nilai $a^{*}$ tepung suweg fase dorman berbeda nyata dengan vegetatif. Tepung suweg fase dorman memiliki $a^{*}$ yang lebih besar dari pada vegetatif. Hal ini menunjukkan bahwa warna tepung fase dorman lebih menuju merah dibandingkan vegetatif. Nilai $a^{*}$ kedua tepung berkisar antara -17 hingga -14 . Berbeda dengan hasil penelitian Nurdyansyah 
Agrisaintifika

Jurnal Ilmu-Ilmu Pertanian

Vol. 1, No. 1, 2017

Hasbullah \& Umiyati, 2017

dkk. (2016), tepung suweg dari beberapa kabupaten di Jawa Tengah memiliki range nilai $a^{*}$ antara 2 sampai 6 . Sedangkan Paramita dkk. (2017) menyatakan bahwa nilai $a^{*}$ tepung suweg dari Gunungpati Semarang 8,12. Nilai $a^{*}$ tepung suweg jauh lebih rendah dibandingkan dengan tepung cassava $(-0,3)$ (Uchechukwu-Agua dkk., 2015); (-0,3 sampai $0,9)$ (Oduro-Yeboah dkk., 2010), tepung talas $(-1,31$ sampai 0,04$)$ (Apriani dkk., 2011), tepung ubi jalar $(-0,27-3,54)$ (Olatunde dkk., 2016); (-2) (Sanoussi dkk., 2013).

Nilai $b^{*}$ tepung suweg fase dorman berbeda nyata dengan vegetatif. Tepung suweg fase vegetatif memiliki $b^{*}$ yang lebih besar dari pada dorman. Hal ini menunjukkan bahwa warna tepung fase dorman lebih menuju kuning dibandingkan vegetatif. Nurdyansyah dkk. (2016) menyampaikan hasil yang berbeda pada tepung suweg dari beberapa kabupaten di Jawa Tengah yang memiliki range nilai $b^{*}$ antara 12-16. Sedangkan Paramita dkk. (2017) menyatakan bahwa nilai $b^{*}$ tepung suweg dari Gunungpati Semarang 10,8. Nilai $b^{*}$ tepung suweg jauh lebih tinggi dibandingkan dengan tepung cassava (11,24) (Uchechukwu-Agua dkk., 2015); (5-10) (Oduro-Yeboah dkk., 2010) tepung talas (4-10) (Apriani dkk., 2011), tepung ubi jalar ((9.89-27.94) (Olatunde dkk., 2016); (10-12) (Sanoussi dkk., 2013).

Nilai chroma tepung suweg fase dorman berbeda nyata dengan vegetatif. Tepung suweg fase vegetatif memiliki nilai chroma lebih besar daripada dorman. Hal ini menunjukkan bahwa intensitas warna tepung suweg fase vegetatif lebih tinggi dibandingkan dorman. Hasil tersebut berbeda dengan range nilai chroma tepung suweg dari beberapa kabupaten di Jawa Tengah yaitu 12-18 (Nurdyansyah dkk., 2016).

Nilai derajat hue tepung suweg fase dorman tidak berbeda nyata dengan vegetatif. Tepung suweg fase dorman memiliki nilai hue yang lebih tinggi daripada vegetatif. Warna tepung suweg fase dorman lebih mendekati coklat ke kuning dibanding vegetatif. Range nilai derajat hue yang dihasilkan berbeda dengan Nurdyansyah dkk. (2016) yang menyatakan pada tepung suweg dari beberapa kabupaten di Jawa Tengah berada pada range
$1,2-1,3$. Nilai derajat hue tepung suweg jauh lebih tinggi dibandingkan dengan tepung talas $(24,2)$ (Baidoo dkk., 2014).

Penilaian sensoris panelis terhadap warna tepung suweg fase dorman dan vegetatif ditunjukkan pada Gambar 1. Pengujian sensoris menggunakan uji ranking terhadap parameter kesukaan, warna lebih coklat dan warna lebih gelap. Semua panelis menyatakan kesukaannya terhadap tepung suweg fase dorman dibandingkan vegetatif. Hal ini ditunjukkan dengan nilai rangking kesukaan tepung suweg fase dorman $100 \%$. Kesukaan panelis akan warna tepung sangat dipengaruhi oleh intensitas warna yang dilihat dan kecerahan.

Parameter rangking warna yang lebih coklat pada tepung suweg dinilai panelis dengan lebih dari $80 \%$ menyatakan bahwa tepung suweg fase vegetatif lebih coklat dari pada dorman. Sedangkan parameter rangking warna tepung suweg yang lebih gelap dinyatakan panelis bahwa lebih dari $90 \%$ panelis menyatakan bahwa tepung suweg fase vegetatif lebih gelap dibandingkan dorman.

Secara visual nampak warna tepung suweg adalah coklat krem Faridah (2005). Sedangkan Hasbullah (2016) melaporkan bahwa tepung suweg dari beberapa Kabupaten di Jawa Tengah memiliki warna coklat. Hal ini terkait juga dengan warna daging umbi suweg yaitu coklat (Yadav dan Singh, 2016). Sedangkan Panja dan Adhikary (2016) menyatakan bahwa beberapa varietas suweg memiliki warna daging umbi yang kuning tetapi kandungan polifenolnya tinggi yaitu berkisar $0,5 \mathrm{mg} / \mathrm{g}$. Kandungan polifenol yang tinggi ini menyebabkan terjadinya pencoklatan enzimatis selama pengolahan menjadi tepung. 
Agrisaintifika

Jurnal Ilmu-Ilmu Pertanian

Vol. 1, No. 1, 2017

Hasbullah \& Umiyati, 2017

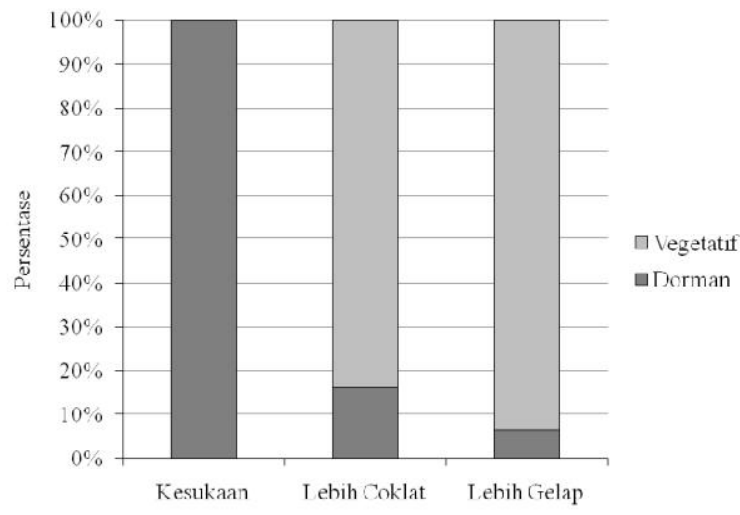

Gambar 1. Persen rangking sensoris warna tepung suweg fase dorman dan vegetative.

Keterkaitan antara penggunaan instrumen dalam pengujian warna tepung suweg dengan uji sensoris dinyatakan dalam uji korelasi pearsons yang ditampilkan dalam Tabel 2. Parameter yang menunjukkan korelasi diantaranya nilai $a^{*}$ dengan rangking kesukaan, $b^{*}$ dengan chroma, $b^{*}$ dengan rangking kesukaan, chroma dengan rangking kesukaan, dan rangking lebih coklat dengan rangking lebih gelap.

Hubungan korelasi antara nilai $a^{*}$ dengan rangking kesukaan memberikan nilai koefisien yang jauh dari 1 dan bernilai positif. Hal ini menunjukkan kedua parameter tersebut memiliki hubungan tetapi tidak erat. Kedua parameter tersebut memiliki hubungan positif dimana apabila nilai $a^{*}$ meningkat maka rangking kesukaan akan meningkat dan sebaliknya.

Hubungan korelasi antara $b^{*}$ dengan chroma memberikan nilai koefisien yang mendekati 1 dan positif. Hal ini menunjukkan kedua parameter tersebut memiliki hubungan yang sangat erat. Kedua parameter tersebut memiliki hubungan positif dimana apabila nilai $b^{*}$ meningkat maka nilai chroma akan meningkat dan sebaliknya.

Hubungan korelasi antara nilai $b^{*}$ dengan rangking kesukaan memberikan nilai koefisien yang jauh dari 1 dan bernilai negatif. Hal ini menunjukkan kedua parameter tersebut memiliki hubungan tetapi tidak erat. Kedua parameter tersebut memiliki hubungan negatif dimana apabila nilai $b^{*}$ meningkat maka rangking kesukaan akan menurun dan sebaliknya.

Tabel 2. Nilai Korelasi Pearsons Warna Tepung suweg fase dorman dan vegetatif

\begin{tabular}{|c|c|c|c|}
\hline \multicolumn{3}{|l|}{ Parameter } & $\begin{array}{c}\text { Pearson } \\
\mathrm{s}\end{array}$ \\
\hline $\mathrm{L}^{*}$ & $x$ & $a^{*}$ & 0,03 \\
\hline$L^{*}$ & $x$ & $b^{*}$ & $-0,31$ \\
\hline$L^{*}$ & $x$ & $\mathrm{C}$ & $-0,35$ \\
\hline$L^{*}$ & $x$ & oh & 0,27 \\
\hline$L^{*}$ & $x$ & $\begin{array}{l}\text { Rangking } \\
\text { kesukaan }\end{array}$ & 0,25 \\
\hline$L^{*}$ & $x$ & $\begin{array}{l}\text { Rangking } \\
\text { lebih coklat }\end{array}$ & $-0,16$ \\
\hline$L^{*}$ & $x$ & $\begin{array}{l}\text { Rangking } \\
\text { lebih gelap }\end{array}$ & $-0,16$ \\
\hline$a^{*}$ & $x$ & $b^{*}$ & $-0,10$ \\
\hline$a^{*}$ & $x$ & $\mathrm{C}$ & $-0,26$ \\
\hline$a^{*}$ & $x$ & oh & $-0,43$ \\
\hline$a^{*}$ & $x$ & $\begin{array}{l}\text { Rangking } \\
\text { kesukaan }\end{array}$ & $0,51^{* *}$ \\
\hline$a^{*}$ & $x$ & $\begin{array}{l}\text { Rangking } \\
\text { lebih coklat }\end{array}$ & 0,04 \\
\hline$a^{*}$ & $x$ & $\begin{array}{l}\text { Rangking } \\
\text { lebih gelap }\end{array}$ & 0,04 \\
\hline$b^{*}$ & $x$ & C & $0,88^{* *}$ \\
\hline$b^{*}$ & $x$ & oh & $-0,29$ \\
\hline$b^{*}$ & $x$ & $\begin{array}{l}\text { Rangking } \\
\text { kesukaan }\end{array}$ & $-0,62^{* *}$ \\
\hline$b^{*}$ & $x$ & $\begin{array}{l}\text { Rangking } \\
\text { lebih coklat }\end{array}$ & $-0,001$ \\
\hline$b^{*}$ & $x$ & $\begin{array}{l}\text { Rangking } \\
\text { lebih gelap }\end{array}$ & $-0,001$ \\
\hline C & $x$ & oh & $-0,26$ \\
\hline C & $x$ & $\begin{array}{l}\text { Rangking } \\
\text { kesukaan }\end{array}$ & $-0,75^{\star *}$ \\
\hline C & $x$ & $\begin{array}{l}\text { Rangking } \\
\text { lebih coklat }\end{array}$ & $-0,007$ \\
\hline C & $x$ & $\begin{array}{l}\text { Rangking } \\
\text { lebih gelap }\end{array}$ & $-0,007$ \\
\hline oh & $x$ & $\begin{array}{l}\text { Rangking } \\
\text { kesukaan }\end{array}$ & 0,14 \\
\hline oh & $x$ & $\begin{array}{l}\text { Rangking } \\
\text { lebih coklat }\end{array}$ & $-0,06$ \\
\hline oh & $x$ & $\begin{array}{l}\text { Rangking } \\
\text { lebih gelap }\end{array}$ & $-0,06$ \\
\hline $\begin{array}{l}\text { Rangking } \\
\text { kesukaan }\end{array}$ & $x$ & $\begin{array}{l}\text { Rangking } \\
\text { lebih coklat }\end{array}$ & $-0,05$ \\
\hline $\begin{array}{l}\text { Rangking } \\
\text { kesukaan }\end{array}$ & $x$ & $\begin{array}{l}\text { Rangking } \\
\text { lebih gelap }\end{array}$ & $-0,05$ \\
\hline $\begin{array}{r}\text { Rangking } \\
\text { lebih coklat }\end{array}$ & $x$ & $\begin{array}{l}\text { Rangking } \\
\text { lebih gelap }\end{array}$ & $1^{* *}$ \\
\hline
\end{tabular}


Agrisaintifika

Jurnal Ilmu-Ilmu Pertanian

Vol. 1, No. 1, 2017

Hasbullah \& Umiyati, 2017

Hubungan korelasi antara nilai chroma dengan rangking kesukaan memberikan nilai koefisien yang mendekati 1 dan bernilai negatif. Hal ini menunjukkan kedua parameter tersebut memiliki hubungan erat. Kedua parameter tersebut memiliki hubungan negatif dimana apabila nilai chroma meningkat maka rangking kesukaan akan menurun dan sebaliknya.

Hubungan korelasi antara rangking lebih coklat dengan rangking lebih gelap memberikan nilai koefisien 1 dan positif. Hal ini menunjukkan kedua parameter tersebut memiliki hubungan yang sangat erat. Kedua parameter tersebut memiliki hubungan positif dimana apabila rangking lebih coklat meningkat maka rangking lebih gelap akan meningkat dan sebaliknya.

\section{DAFTAR PUSTAKA}

Apriani, R.R.N., Setyadjit, M. Arpah. 2011. Karakterisasi Empat Jenis Umbi Talas Varian Mentega, Hijau, Semir, Dan Beneng Serta Tepung Yang Dihasilkan Dari Keempat Varian Umbi Talas. Jurnal IImiah dan Penelitian IImu Pangan 1(1). https://jurnaldanmajalah.wordpress.com/ $\underline{2011 / 01 / 04 / 6 /}$

Baidoo, E.A., P. T. Akonor, C. Tortoe. 2014. Effect of Pre-treatment and Storage Condition on the Physicochemical Properties of Taro (Colocasia esculenta [L.] Schott) Flour. International Journal of Food Science and Nutrition Engineering 4(4): 91-97. DOI: 10.5923/j.food.20140404.01

Faridah, D. N. 2005. Sifat Fisiko-kimia Tepung Suweg (Amorphopallus campanulatus B1) dan Indeks Glikemiksnya. Jurnal. Teknol. dan Industri Pangan. 8(3):254259.

Hasbullah, U.H.A. 2016. Sifat Sensoris Dan Principal Component Analysis Tepung Suweg di Karisidenan Surakarta. Jurnal IImiah Teknosains 2(2):107-111.

\section{KESIMPULAN}

Secara instrumental terdapat perbedaan yang nyata antara warna tepung suweg fase dorman dan vegetatif pada parameter chroma, nilai $a^{*}, b^{*}$, dan $L^{*}$. Secara sensoris penelis lebih menyukai tepung pada fase dorman. Panelis menilai tepung suweg fase vegetative lebih coklat dan gelap. Terdapat korelasi antara beberapa parameter instrumental dengan sensoris.

\section{UCAPAN TERIMA KASIH}

Penelitian ini merupakan bagian dari penelitian tepung suweg fase dorman dan vegetatif yang didanai Lembaga Penelitian dan Pengabdian kepada Masyarakat (LPPM) Universitas PGRI Semarang melalui program hibah penelitian dosen pemula.

Hasbullah, U.H.A. dan R. Umiyati. 2016. Laporan Penelitian Dosen Pemula. Dampak Fase Dorman dan Fase Vegetatif Terhadap Karakteristik Fisik, Kimia dan Sensoris Tepung Umbi Suweg (Amorphophallus campamulatus). LPPM Universitas PGRI Semarang.

Hasbullah, U.H.A., F. Nurdyansyah, B. Supriyadi, R. Umiyati, dan R.M.D. Ujianti. 2017. Sifat Fisik Dan Kimia Tepung Umbi Suweg (Amorphophallus campamulatus $\mathrm{BI})$ di Jawa Tengah. Jurnal Pangan dan Gizi 7(1).

Mcguire, R.G., 1992. Reporting of Objective Color Measurements. HortScience 27, 1254-1255.

Nurdyansyah, F., U.H.A. Hasbullah, B. Supriyadi, R. Umiyati, dan R.M.D. Ujianti. 2016. Karakter Warna Tepung Umbi Suweg (Amorphophallus Campamulatus $\mathrm{BI})$ di Jawa Tengah. Prosiding Seminar Nasional Hasil Penelitian LPPM UPGRIS. Sabtu, 22 Oktober 2016. ISBN: 978-602-14020-3-0. 
Oduro-Yeboah, C., P-N.T. Johnson, E. SakyiDawson, and A. Budu. 2010. Effect of processing procedures on the colorimetry and viscoelastic properties of cassava starch, flour and cassava-plantain fufu flour. International Food Research Journal 17: 699-709.

Olatunde, G.O., F. O. Henshaw, M. A. Idowu dan K. Tomlins. 2016. Quality attributes of sweet potato flour as influenced by variety, pretreatment and drying method. Food Science \& Nutrition 2016; 4(4): 623-635. doi: 10.1002/fsn3.325

Paramita, O., Wahyuningsih, and M. Ansori. 2017. Chemical purification of Gunungpati elephant foot yam flour to improve physical and chemical quality on processed food. AIP Conference Proceedings 1818, 020041. doi: 10.1063/1.4976905.

http://aip.scitation.org/doi/pdf/10.1063/1.4 976905

Panja, P. and S. Adhikary. 2016. Diversity Of Physical And Bio-Chemical Properties In Some Elephant Foot Yam (Amorphophallus Paeoniifolius) Cultivars At Harvest Fresh Stage. The Bioscan 11(2): 1193-1198. https://www.researchgate.net/publication/ 309781958 DIVERSITY OF PHYSICAL AND BIO-

CHEMICAL PROPERTIES IN SOME E LEPHANT FOOT YAM AMORPHOPHA LLUS PAEONIIFOLIUS CULTIVARS A T HARVEST FRESH STAGE
Richana, N dan T.C Sunarti, 2004. Karakterisasi Sifat Fisikokimia Tepung Umbi dan Tepung Pati dari Umbi Ganyong,Suweg, Ubi Kelapa, dan Gembili. J.Pascapanen 1(1):29-37

Sanoussi A. F , Dansi A, Bokossa-yaou I, Dansi M, Egounlety M, Sanni L.O and Sanni. A. 2013. Formulation and biochemical characterization of sweet potato (Ipomoea batatas) based infant flours fortified with soybeanand sorghum flours. Int.J.Curr.Microbiol.App.Sci 2(7): 22-34. http://www.ijcmas.com/vol-27/Sanoussi\%20A.et\%20al.pdf

Septiani, D., Y. Hendrawan, dan R. Yulianingsih. 2015. Uji karakteristik fisik, kimia dan organoleptik pembuatan tepung umbi suweg (Amorphophallus campanulatus B) sebagai bahan pangan alternatif. Jurnal Bioproses Komoditas Tropis 3(1).

Uchechukwu-Agua, A.D., Oluwafemi J. Caleb, Marena Manley \&Umezuruike Linus Opara. 2015. Effects of storage conditions and duration on physicochemical and microbial quality of the flour of two cassava cultivars (TME 419 and UMUCASS 36), CyTA - Journal of Food, 13:4, 635-645, DOI: 10.1080/19476337.2015.1029524.

Yadav, A. and S. Singh. 2016. Physicochemical properties of selected varieties of elephant foot yam (Amorphophallus paeoniifolius). International Journal of Home Science 2(3): 353-357. http://www.homesciencejournal.com/arch ives/2016/vol2issue3/PartF/2-3-54.pdf 